\title{
Evaluation of Heating and Cooling Loads for a Well-Insulated Single-Family House under Variable Climate Pattern
}

\author{
Aleksejs PROZUMENTS ${ }^{1 *}$, Arturs STAVECKIS ${ }^{2}$, Jurgis ZEMITIS ${ }^{3}$, Diana BAJARE ${ }^{4}$ \\ ${ }^{1-3}$ Department of Heat Engineering and Technology, Faculty of Civil Engineering, \\ Riga Technical University, Riga, Latvia \\ 1,2WWL Houses Ltd., Kalnciems, Latvia \\ ${ }^{4}$ Department of Building Materials and Products, Faculty of Civil Engineering, Riga Technical University, \\ Riga, Latvia
}

\begin{abstract}
Single family houses consume substantially more thermal energy per floor area compared to multi-apartment buildings to satisfy space heating or cooling demand. Over the past decades there has been an undisputed evidence of a temperature rise across the world that has led to a growing concern of more extreme weather patterns and regular seasonal heat waves globally. As such, building occupants are at a continuously growing risk to overheating exposure inside the premises. Within the framework of this study a single-family house was examined with respect to its thermal performance in warm and cold seasons. A simulation model was developed in IDA-ICE software to evaluate annual thermal energy demand for a reference scenario, 3 shading scenarios and for an optimized scenario. At an optimized scenario that incorporates mechanical ventilation with a heat recovery unit and enhanced thermal performance of the external building elements, the annual thermal energy demand in the proposed single-family house was reduced by $39.5 \%$ compared to the reference scenario, which is a significant step towards meeting nearly zero energy building criteria.
\end{abstract}

Keywords - Building energy consumption; building energy simulation; heating and cooling loads; single-family house

\section{INTRODUCTION}

Building energy efficiency subject extends well beyond the building stock-related boundaries and is a major driver to facilitate economic and social development on a national and regional scale, as buildings account for over $40 \%$ of total energy use [1], [2]. Single family houses consume substantially more energy per floor area compared to multi-apartment buildings to satisfy space heating or cooling demand [3]. Furthermore, studies show that an extensive number of single-family houses constructed before 2000 across EU are in need for renovation [4], therefore thermal retrofitting of this building category has a meaningful impact on the overall building stock energy efficiency of the respective region.

Developed countries feature an existing building stock that will last for many decades, hence an increasing focus will be addressed towards major energy retrofitting programs of the existing buildings, driven by the long-term cost benefit [5]. On the other hand, it is projected that by 2050 in Europe and the U.S. the large portion of the existing building stock

\footnotetext{
* Corresponding author.

E-mail address: aleksejs.prozuments@rtu.lv
} 
will be either renovated or replaced by new buildings, therefore it will be the new building stock that will dominate the urban energy demand in those regions [6]. Regardless, the rate at which energy efficiency policies are being adopted and implemented in practice very strongly depends on the social, economic and technological development of the region and regional development programs [7].

The national regulatory environment addressing building energy efficiency in Latvia emerged in 2002, stipulating more stringent thermal performance criteria. In 2004, in line with becoming an EU member state, Latvia began adopting a series of EU policies targeted at substantial reduction in building energy consumption [8]. Due to the lack of stringent and defined regulatory environment prior to the 2000 s, the bulk of the existing building stock in Latvia that had not undergone deep renovation measures features poor thermal insulation, excessive outdoor air infiltration and condensation occurrence within the external wall structures [9]-[12].

As part of building thermal performance improvement strategies, proper insulation of external building elements have shown to be the most financially reasonable and efficient measure to decrease energy consumption not only across residential and commercial buildings, but also in industrial [13], historical [12], military and unclassified building stock [14]-[16]. Building envelope has a crucial role in maintaining heat balance and preserving heat loss from the building, accounting for up to $60 \%$ of building thermal performance [17]. The long-term feasibility of enhancing building thermal insulation as an energy conservation measure, therefore, specifically applies to mild and cold climate regions that are characterized by prolonged period of space heating demand. Moreover, as the focus on energy efficient buildings with regards to embodied and operational energy is growing across the world, more rigorous attention has to be paid to the choice of building materials [18], [19].

In addition, over the past decades there has been an undisputed evidence of rising temperatures across the world, that has led to a growing concern of more extreme weather patterns and regular seasonal heat waves globally [20], [21]. As such, building occupants are at an ever-increasing risk to overheating exposure [22] which is already emerging as an existing issue in many buildings [23]. With an advent of higher temperature patterns in both winter and summer seasons, it is projected that the demand for space heating will be gradually decreasing over the coming years, while the building cooling requirement will be continuously increasing with respect to heating/cooling energy consumption per floor area.

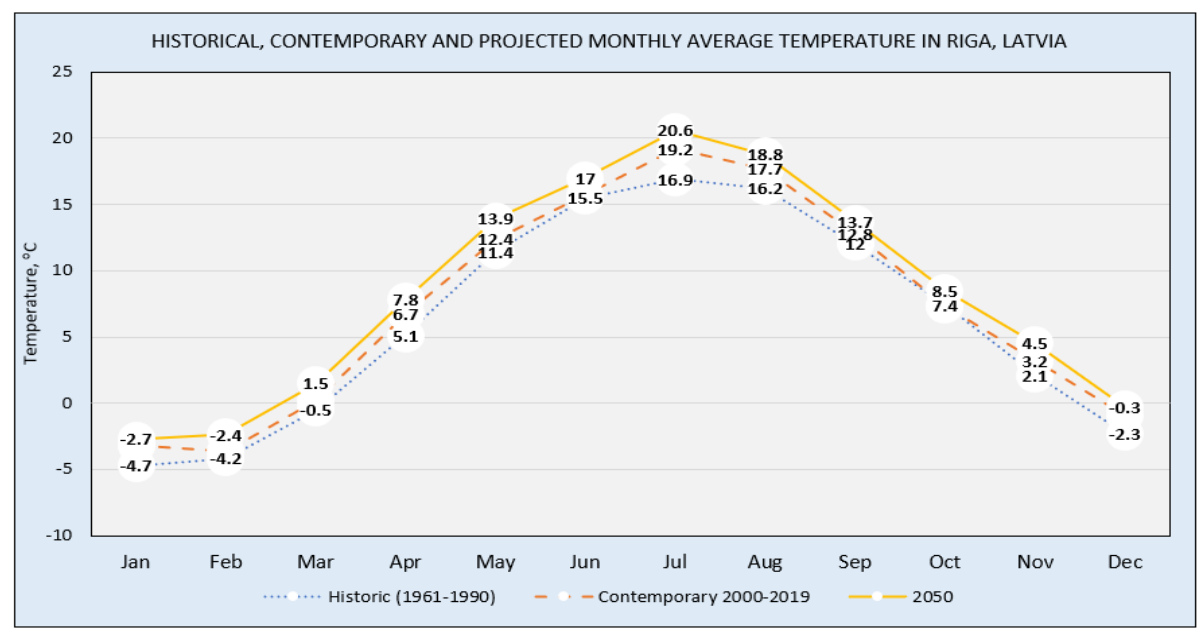

Fig. 1. Historical, contemporary, and projected monthly temperature averages for Riga, Latvia. 
Figure 1 compiles the average historical (1961-1990), contemporary (2000-2019) and projected (2050) temperature data for Riga, Latvia. The chart suggests gradual and consistent seasonal temperature rise, that implies shifting focus from preventing excessive heat loss in the cold season (late fall thru early spring) to preventing risk of overheating in the warm season (late spring thru early fall) in the buildings. Majority of the existing national building stock in Latvia has been constructed during the period of 1945-1990, featuring rigid external building envelope with little or no consideration for mechanical ventilation systems that would ensure adequate indoor environmental quality within premises [24]. A number of these buildings have undergone façade renovation (replacing or adding thermal insulation layer) and window replacement that has led to higher thermal resistance (double, triple pane windows, lower $U$-values) and thus improving the thermal performance in the cold season. However, these measures have somewhat compromised the indoor environment in the warm season, leading to higher risk of overheating and moisture accumulation.

In line with the advent of higher seasonal temperatures, recent studies suggest that modern buildings are at higher risk of overheating due to their architectural features such as increased surface area of glazing, as well as enhanced building airtightness level [23]. Glazed facades and windows compromise building's thermal resistance in both cold and warm season. Furthermore, window frames are essential elements of a building envelope that contribute to even greater heat loss [25], that in combination with glazing may result in up to $50 \%$ of total building heat loss [26], [27]. A comparative building insulation material analysis conducted by Kumar et al. [17] have shown that buildings featuring higher thermal transmittance are more cost-effective in regions with higher cooling demand, whereas buildings characterized by lower thermal transmittance are more cost-effective in regions with higher heating demand.

Internal and external shading elements are widely used in nearly-zero energy building applications, as it is an effective way to address the risk of overheating, and thus facilitate energy conservation [28]. According to a simulation study, external shading applications have a potential to decrease building cooling demand by $90 \%$ [29], which has a direct contribution to both indoor environmental quality and building energy consumption [30].

In order to improve building energy efficiency a multidisciplinary approach is required, that addresses various combined factors such as building's architectural features, building materials, insulation quality of the building envelope, HVAC operation, as well as occupants' behaviour [31].

Mechanical ventilation system is an effective measure of diluting and removing indoor air contaminants and reducing risks of adverse health effects posed to building occupants that are associated with poor and insufficient ventilation [32]-[34]. While natural ventilation is still prevalent in most buildings across the world with respect to fresh air supply and air exchange, outdoor environments and people's habits have changed rather significantly within the past decades largely due to economic growth and global trends [35] that in turn are leading to wider implementation of mechanical ventilation systems in buildings. Moreover, in pursuance to reduce heat loss and moisture build-up in building structural elements more focus have been drawn towards building airtightness [36] that greatly contributes to the cost efficiency and feasibility of mechanical ventilation system implementation in the building infrastructure.

Heating, air conditioning and ventilation (HVAC) systems account for around $40 \%$ of energy consumption in the building sector [37], [38] and as requirements attributed to indoor environmental quality are gradually becoming stricter, this ratio is expected to rise in future. The European Union's carbon optimization plan assumes that the building sector will reduce carbon dioxide emissions by $80 \%$ by 2050 compared to 1990 levels [39], [40]. Reaching this 
target will require major changes in the design, operation and maintenance of buildings and their integrated heating, cooling and ventilation systems. To achieve this goal, conventional solutions, and the types of systems currently in use need to be reconsidered. At the same time, new building regulations focus on the airtight construction, which in many cases deteriorate indoor air quality, human wellbeing and productivity [41].

The overriding national and European goals for energy saving in the building industry are incorporated into specific implementation guidelines. They provide a gradual increase in the energy efficiency of the building, which is expressed by limiting the permitted annual primary energy requirement.

\section{Methodology}

\subsection{Simulated Building Profile and Prerequisites}

The objective of this study was to examine and compare the annual single-family building energy demand for heating and cooling purposes under implementation of various passive (shading) and active (MVHR $\dagger$ ) building energy interventions. Passive interventions included internal and external shading elements, while an active intervention incorporated MVHR system, which is considered as one of the most efficient building energy conservation strategies (along with building envelope enhancements) and thus, viewed as an optimized scenario within the framework of this study.

As such, a single-family house was examined with regards to its thermal performance in warm and cold seasons. A reference building model was developed in Indoor Climate and Energy building performance simulation software (IDA-ICE), which is a third-party authorized and validated indoor climate and building energy modelling tool [31].

The designed building consists of ecological building materials, substantiating energy efficiency with the calculation of the building energy consumption balance, microclimate and comfort analysis.

The examined building is a semi-detached single-family house with one floor and two separate housing units. The basement is primarily used as a supplementary living space and also provides technical functional space. Each unit has two bathrooms, three bedrooms, one combined living room with a kitchen and corridor. In this context the following considerations are accounted for:

- Basic determination of the input data requirements and thermal performance strategy, depending on the energy concept;

- Consideration of the energy concept, with recommendations for sustainability, compliance with nZEB.

The following building energy regulations were applied to perform building's energy simulation:

- LBN 003-19 - Building climatology;

- LBN 231-15 - Heating and ventilation of residential and public buildings;

- LBN 002-19 - Thermal engineering of building enclosing structures.

Energy and comfort analysis was performed in compliance with the following regulations:

- EN 12831-1:2017 - Energy assessment of buildings;

- EN 16798-3:2017 - Energy performance of buildings - Ventilation for buildings;

- CIBSE TM59 - Design methodology for the assessment of overheating risk in homes;

- DIN V 18599-09 - Energy assessment of buildings;

\footnotetext{
$\dagger$ Mechanical ventilation system with heat recovery.
} 
- EN ISO 7730:2006-05 - Ergonomics of the thermal environment - Analytical determination and interpretation of thermal comfort by calculating the PMV and PPD index and criteria for local thermal comfort;

- EN 15251:2012-12 - Input parameters for the indoor climate for the design and evaluation of the energy efficiency of buildings - indoor air quality, temperature, light and acoustics;

- DIN 1946-6 - Ventilation and air conditioning - Part 6: Ventilation for residential buildings.

\subsection{Simulation Model and External Building Elements}

The calculations of energy balance and thermal comfort were performed in IDA-ICE software. The physical boundary conditions, system properties and thermal loads were configured individually. The aim of the developed simulation model was to evaluate the prospect of a low energy building and to examine annual thermal energy demand in the building to provide analysis of different external shading options and optimized low-energy strategy targeted at reduction of annual thermal energy demand.

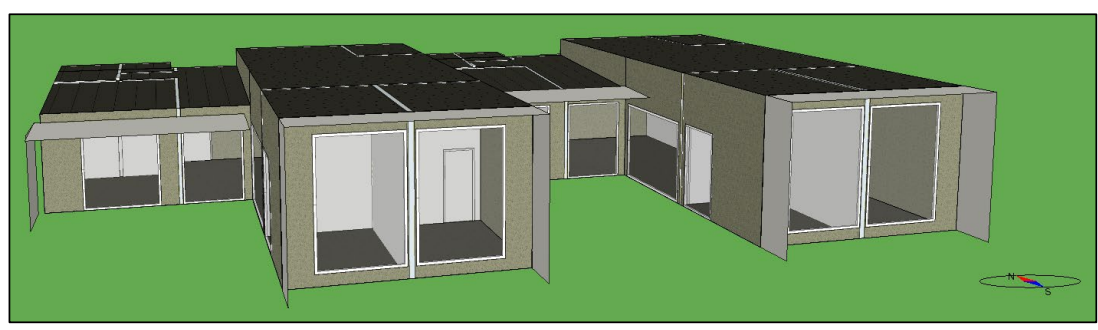

Fig. 2. Rendering of the simulation model.

The rendering of the simulation model is shown in Fig. 2. The shading by the building itself and constructions were taken into account in the model. The building orientation is fixed. The definition of the ventilation and air-conditioning systems and the system configurations were carried out considering building occupancy and energy use profile (see section 2.3.). The weather data was retrieved from the data records of the LBN 003-19 regulation for the exact project location (Riga), with the seasonal weather extremes as follows: summer: $26.1{ }^{\circ} \mathrm{C}$ at $47 \%$ relative humidity $(\mathrm{RH})$; winter: $-20{ }^{\circ} \mathrm{C}$ at $90 \% \mathrm{RH}$.

For the building envelope, the structural elements listed below were used in the thermal simulations. Only the consideration of the thermally relevant layers was necessary (thermal conductivity and heat storage capacity) for the given simulation model. The thermal profile of the building envelope is compiled in Table 1.

The simulation was based on the following energy properties attributed to the windows:

- $U$-value window incl. frame $U_{w}=0.75 \mathrm{~W} /\left(\mathrm{m}^{2} \mathrm{~K}\right)$;

- Total energy transmittance $g_{\text {tot }}=0.50$;

- Light transmittance $\tau_{\mathrm{D} 65}=0.4$;

- Frame fraction: $10 \%$.

External building envelope must meet airtightness criteria to avoid excessive outdoor air infiltration that may lead to condensation risk, as well as to an increased energy consumption for space heating [42]. The average infiltration rate and the demand for heating energy increases almost linearly with the air tightness of the building at n50. Higher energy savings, 
enhanced indoor comfort and noise protection are further advantages of an airtight building envelope [43].

TABle 1. Thermal Profile of the BuILding ENVElope For Simulated BuILDings

\begin{tabular}{lllll}
\hline Building envelope & Area $\boldsymbol{A}, \mathbf{m}^{\mathbf{2}}$ & $\boldsymbol{U}, \mathbf{W} /\left(\mathbf{m}^{\mathbf{2}} \mathbf{K}\right)$ & $\boldsymbol{U} \cdot \boldsymbol{A}, \mathbf{W} / \mathbf{K}$ & \% of total \\
\hline Walls above ground & 301.72 & 0.14 & 41.84 & 16.27 \\
EW2 & 110.78 & 0.16 & 17.52 & 6.82 \\
EW1 & 190.93 & 0.13 & 24.32 & 9.46 \\
Roof & 275.08 & 0.09 & 24.48 & 9.53 \\
J1 & 86.24 & 0.10 & 8.76 & 3.41 \\
J2 & 188.84 & 0.08 & 15.72 & 6.12 \\
Floor towards ground & 277.58 & 0.35 & 97.21 & 37.83 \\
$\quad$ G1 & 277.58 & 0.35 & 97.21 & 37.83 \\
Windows & 89.15 & 0.75 & 66.86 & 26.02 \\
Doors & 10.36 & 1.67 & 17.31 & 6.74 \\
Thermal bridges & & & 9.25 & 3.60 \\
\hline Total & $\mathbf{9 5 3 . 8 9}$ & $\mathbf{0 . 2 7}$ & $\mathbf{2 5 6 . 9 6}$ & $\mathbf{1 0 0 . 0 0}$ \\
\hline
\end{tabular}

The following building tightness criteria must be complied with in order to meet the nZEB (nearly zero energy building) requirements: target value of the outside area-related air exchange $n_{50}=0.6 \mathrm{~h}^{-1}$.

The air tightness is determined by means of a pressure differential test (blower door measurement) according to EN 13829 after the building envelope has been installed.

\subsection{Indoor Thermal Comfort Criteria}

Within the framework of this study the feasibility of natural ventilation was assessed to evaluate whether similar thermal comfort level and heating energy consumption can be achieved with the concept of employing natural ventilation, as with mechanical ventilation. In such scenario, indoor air quality requirement is satisfied by the air flow through opening the windows of the building. No energy is required for the air movement, nor are the shafts for air distribution. This concept is determined by the climatic conditions. The outdoor air humidity cannot be adjusted, and the air exchange rate can only be controlled via means of opening or closing the windows. Under the climatic conditions of the examined single-family house, natural ventilation would assist in maintaining indoor comfort and reduce energy consumption for cooling in summer, however, it would compromise building's thermal performance in winter. This risk is being investigated as part of this study. There are various strategies that can be used for natural ventilation of a building: one-sided ventilation, crossventilation, automated natural ventilation. Within the scope of this study, a simplified method described in EN 12831 is implemented. It is assumed that the occupied zones have fixed air exchange per hour $n=0.5 \mathrm{~h}^{-1}$.

The building's heating load is calculated in accordance with EN 12831 and the national supplement. The required indoor conditions are specified in Table 2. 
TABLE 2. INDOOR THERMAL COMFORT CRITERIA IN SIMULATED BUILDING

\begin{tabular}{lllllll}
\hline $\mathbf{N r}$ & Zone & Setpoints, ${ }^{\circ} \mathbf{C}$ & $\begin{array}{l}\text { Occupancy, } \\
\text { people }\end{array}$ & Lighting & Equipment & $\begin{array}{l}\text { Activity, } \\
\text { met }\end{array}$ \\
\hline 1 & $\begin{array}{l}\text { Bedroom } \\
21 / 25\end{array}$ & 2 & & $80 \mathrm{~W}$ & 1.0 \\
2 & $\begin{array}{l}\text { Living room } \\
+ \text { Kitchen }\end{array}$ & $21 / 25$ & 4 & $\begin{array}{l}\text { LED lighting } \\
\left(3 \mathrm{~W} / \mathrm{m}^{2}\right)\end{array}$ & $450 \mathrm{~W}$ & 1.6 \\
3 & Bathroom & $24 /-$ & - & - & - \\
4 & Entrance & $15 /-$ & - & - & - & - \\
\hline
\end{tabular}

Furthermore, no additional heating capacity was considered. This suggests that at the designed outdoor air temperature, sufficient building heating is only attainable with continuous primary heating operation (without night reduction). At this stage, the energy required to heat the domestic water was not included.

The total heat output in the rooms due to people presence is calculated in accordance with EN ISO 7730 and VDI 2078 depending on the room air temperature. An activity level of 1.0 1.6 met and clothing of $0.50 \pm 0.50$ clo was used as a basis. The moisture release of the people was considered depending on the underlying level of activity in accordance with VDI 2078.

In order to obtain reliable results with the simulations, it was necessary to map the use of the building (internal heat loads) as close to real scenario as possible. It was assumed that the heat loads from people, lighting and technical devices occur exclusively during the periods of occupancy and the equipment use according to the schedule pattern laid out below. The simulations were based on the following schedule profiles (Fig. 3.) in accordance with CIBSE TM 59 guidelines [44].

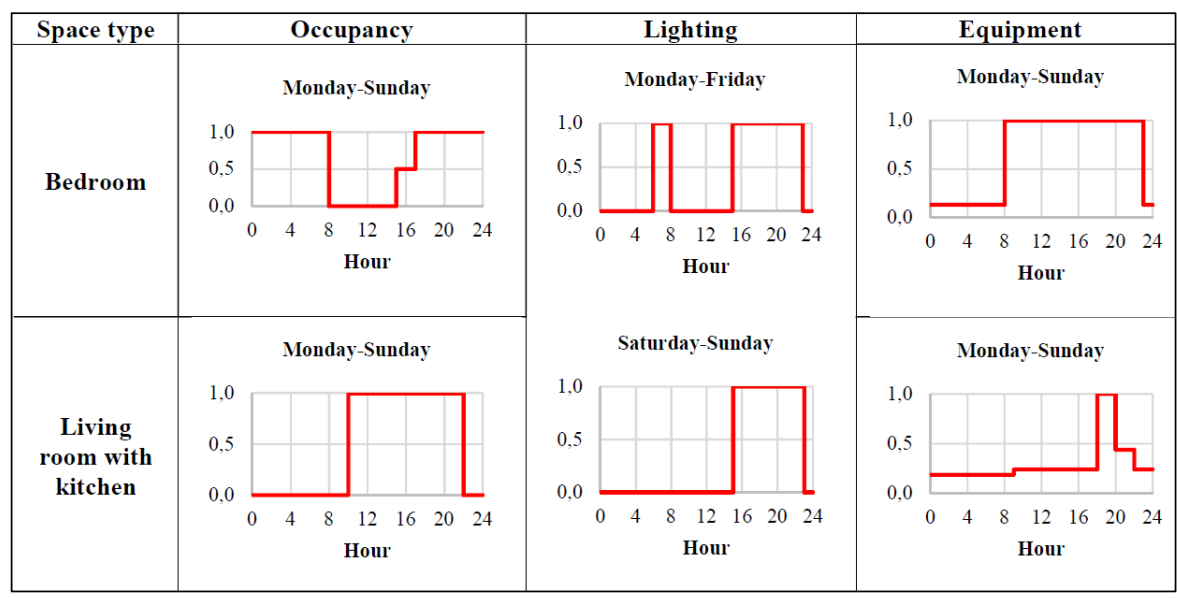

Fig. 3. Occupancy, lighting and equipment use profile in the simulated building.

\subsection{Modelled Energy Consumption Scenarios}

The majority of the single-family houses in the Baltic region do not feature modern or optimized energy conservation features such as mechanical ventilation system with heat recovery, and largely rely on natural ventilation through infiltration and opening of the windows, as well as building on building envelope to maintain the desirable air quality and heat balance [45]. However, fundamental steps have been taken in majority of single-family buildings to reduce the effect of overheating by implementing various shading techniques, 
such as external shading (trees, overhangs, outside window blinds, shutters etc.) or internal shading (internal window blinds, curtains etc.) elements, that have the potential to significantly improve indoor environmental quality [30]. Based on the most commonly applied shading variations across single family houses in the Baltic region, 3 shading scenarios (along with the baseline scenario with no shading and an optimized scenario with a mechanical ventilation system incorporating heat recovery) were developed to simulate building energy demand throughout a year.

In total, five building energy consumption scenarios were examined within the framework of this study.

1. Building without external shading elements;

2. Building with an external shading (external window blinds);

3. Building with insulated shading (internal window roller shade);

4. Building with insulated shading (internal window roller shade + solar gain accumulation);

5. An optimized building with enhanced thermal properties of the external elements, incorporating mechanical ventilation system, heat recovery unit and no external shading.

When applying the external/internal shading strategies in scenarios 2 and 3 , the threshold level for solar radiation was assumed $200 \mathrm{~W} / \mathrm{m}^{2}$. An operation strategy for scenarios 2 and 3 was established, so that throughout the year the external or insulated shading operates from $10 \mathrm{pm}$ to $8 \mathrm{am}$ and when solar radiation intensity exceeds the defined threshold value. On the contrary, scenario 4 excludes solar radiation reduction during the winter period in order to optimize solar heat gain accumulation. Winter period is assumed from $15^{\text {th }}$ October till $15^{\text {th }}$ March. Solar heat gain accumulation was modelled in IDA-ICE software based on the builtin algorithm, which considers the thermal capacity properties of the materials.

The parameters for the simplified shading model are specified as follows:

- Multiplier for $g_{\text {tot }}: 0.2$;

- Multiplier for short-wave shading coefficient: 0.15;

- Multiplier for $U$-value: 0.8 (insulated) and 1.0 (non-Insulated);

- Diffusion factor: 1.0.

\section{RESUlts AND DiscusSiON}

The simulation results show the maximum required load during cold and warm seasons (Fig. 4). The heating load calculation was carried out as a static climatic analysis, while the cooling load - as a dynamic analysis.

As per the simulation, the maximum heating load in all 4 scenarios is $15.6 \mathrm{~kW}$, as none of the three implemented shading scenarios affect heating energy consumption of the building. In turn, the cooling load requirement differ substantially when external shading is applied. However, as it is seen in Fig. 4, the differences in the cooling loads across all 3 shading scenarios are negligible. Based on the results obtained, it can be concluded that a significant reduction in the ballpark of $50 \%$ in the cooling load is driven by the integration of external/internal shading. 


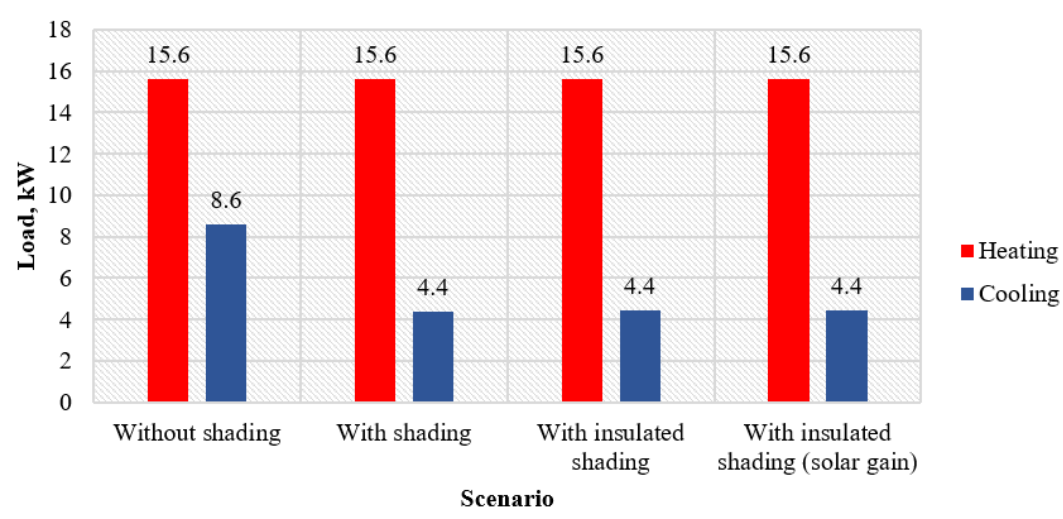

Fig. 4. Maximum required heating and cooling loads across four reviewed scenarios (1-4).

Fig. 5 summarizes the annual energy requirement to meet building's space heating demand across the four scenarios. The chart suggests that the lowest energy consumption would be attained by eliminating any shading elements $\left(111.9 \mathrm{kWh} / \mathrm{m}^{2}\right)$, while integrating the external window blinds would incur highest annual energy consumption for space heating $\left(123.8 \mathrm{kWh} / \mathrm{m}^{2}\right)$. Even though the shading elements do not interfere with the internal heating loads (Fig. 4), they partially do interfere with the solar heat penetration in the winter (based on the defined solar radiation threshold setpoint), increasing the primary energy demand for space heating. Scenarios 2 and 3 account for excessive solar heat gains. When the incident solar radiation exceeds $200 \mathrm{~W} / \mathrm{m}^{2}$, the external shading is activated, thus preventing the solar heat gains entering the room.

In turn, if insulated shading is used in conjunction with the strategy of heat gain accumulation (scenario 3), required space heating energy is only slightly higher than that with no shading. This is due to the fact that scenario 3 allows for solar heat gain utilization during the winter by optimizing solar heat gain during the winter and rejecting solar heat gain during the summer.

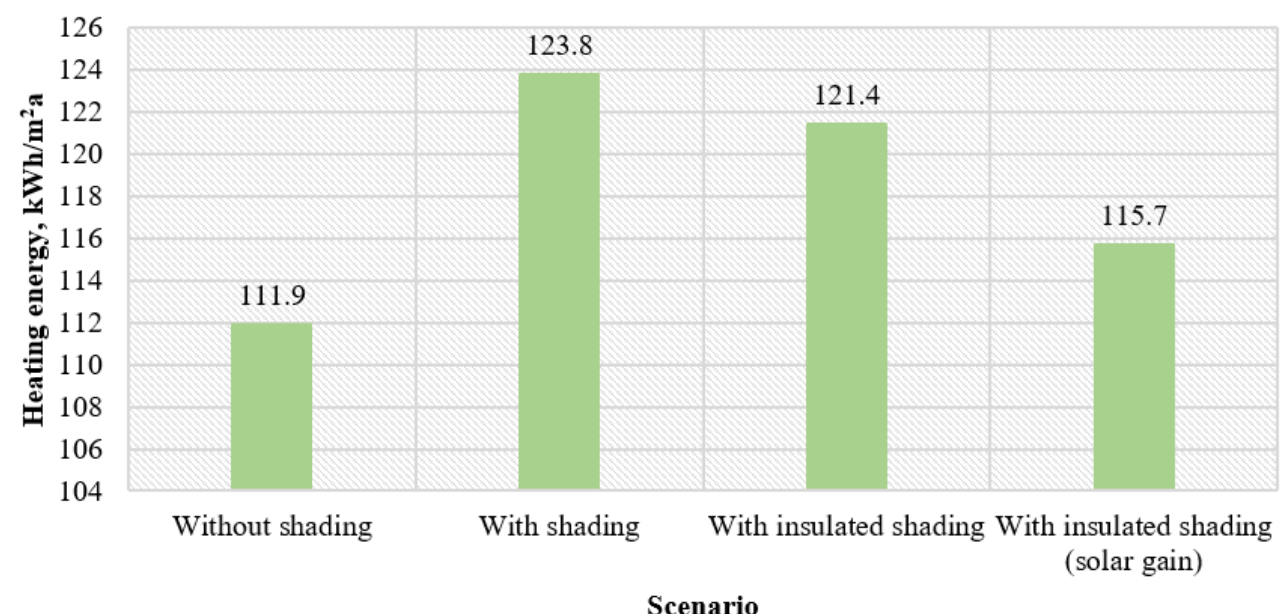

Fig. 5. Annual energy demand for space heating at 4 scenarios with natural ventilation. 
It can be seen that the obtained results in all 4 scenarios greatly exceed the nZEB threshold which in Latvian climate is set to $40 \mathrm{kWh} / \mathrm{m}^{2}$ with respect to the annual space heating energy demand. This significant divergence is attributed to the fact that a simplified natural ventilation mode was used in the simulation. As such, to provide the building occupants with the adequate and sufficient volume of fresh air in the winter season, the building is supplied with the outdoor air without any consideration of pretreatment, thus, inevitably increasing the annual heating demand. Several studies suggest that infiltration and natural ventilation induced losses account for $30 \%$ to $50 \%$ of the total heating load in the buildings, however, by implementing heat recovery in the system, the majority of this otherwise wasted heat can be retained via heat exchanger [46], [47].

Ventilation systems with heat recovery units offer great energy savings for buildings, both in summer and winter, and this strategy is deemed highly more effective than window replacement or adding an insulation layer on the external walls [4], [48]. Depending on the air tightness and the insulation level properties of the building, heat recovery systems have the potential to recover up to $90 \%$ of the ventilation heat losses [49]-[51].

Mechanical ventilation allows precise airflow control with respect to the building's occupancy [52]. Therefore, within the scope of this study an optimized model for the same building was developed. It was assumed that building orientation, shape and façade layout remained unchanged. As the building orientation is limited to the existing landscape, the following adjustments were incorporated in the optimized model:

1. Integration of mechanical ventilation system;

2. Integration of heat recovery unit;

3. Thermal performance improvement of external building elements (lowering U-values).

The parameters of the optimized building simulation model are shown in Fig. 6 . The parameters of the optimized building simulation model are shown in Fig. 6 (ventilation operation schedule), and Table 3 (thermal conductivity values for external building elements).

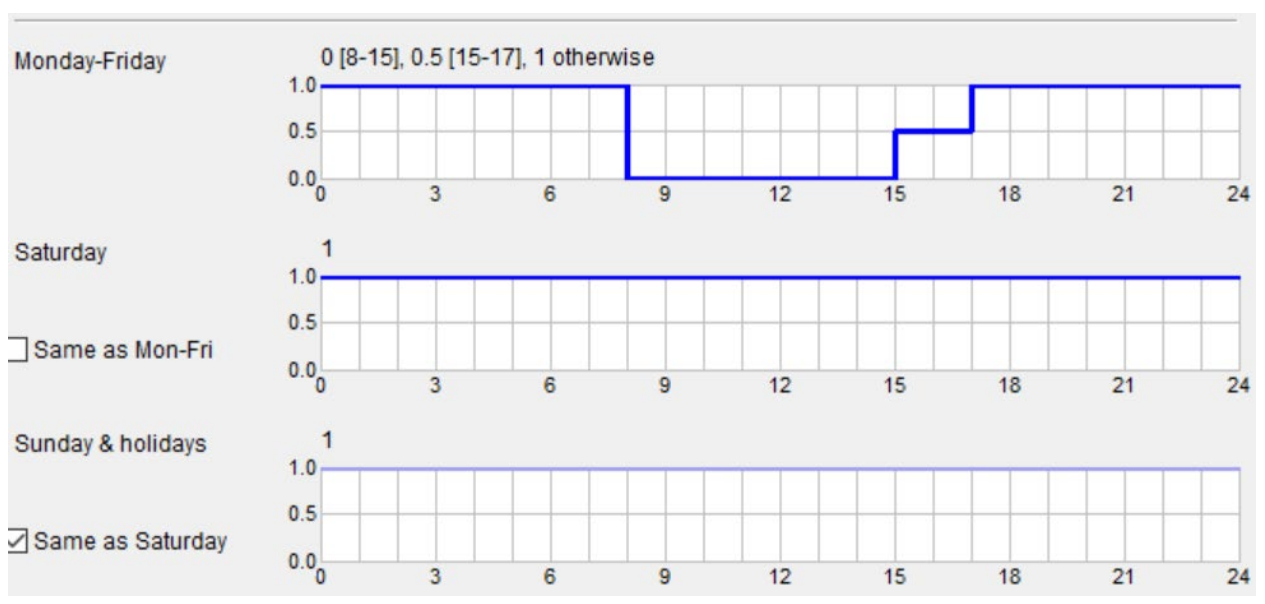

Fig. 6. Optimized building simulation model - mechanical ventilation system equipped with heat recovery unit: mechanical ventilation operation schedule. 
TABLE 3. $U$-VALUES OF THE EXTERNAL BUILDING ELEMENTS

\begin{tabular}{lllll}
\hline Building envelope & Area, $\mathbf{m}^{\mathbf{2}}$ & $\boldsymbol{U}$-value & $\boldsymbol{U} \cdot \boldsymbol{A}, \mathbf{W} / \mathbf{K}$ & \% of total \\
\hline Walls above ground & 449.95 & 0.13 & 55.50 & 28.07 \\
EW2 & 181.14 & 0.16 & 28.64 & 14.49 \\
EW1 & 259.82 & 0.10 & 26.86 & 13.59 \\
Roof & 314.99 & 0.09 & 27.88 & 14.10 \\
J1 & 90.14 & 0.10 & 9.16 & 4.63 \\
J2 & 224.85 & 0.08 & 18.72 & 9.47 \\
Floor towards ground & 319.67 & 0.10 & 32.48 & 16.43 \\
Windows & 89.15 & 0.74 & 65.97 & 33.37 \\
Doors & 10.36 & 4.05 & 41.97 & 21.23 \\
Thermal bridges & & & -26.11 & -13.21 \\
\hline Total & $\mathbf{1 1 7 5 . 1 3}$ & $\mathbf{0 . 1 7}$ & $\mathbf{1 9 7 . 6 9}$ & $\mathbf{1 0 0 . 0 0}$ \\
\hline
\end{tabular}

Mechanical ventilation system equipped with the heat recovery unit would decrease the annual energy demand for the examined single-family house from $111.9 \mathrm{kWh} / \mathrm{m}^{2}$ to $67.8 \mathrm{kWh} / \mathrm{m}^{2}$ under contemporary climate pattern (Fig. 7) which is a $39.5 \%$ reduction compared to the reference building with no shading elements. Under the projected climate pattern (2050) the combined annual energy consumption decrease would amount to $41.5 \%$. Although the optimized simulation model would result in significant annual thermal energy savings, it would not be sufficient to reach nZEB threshold. Nevertheless, the developed model is a cost optimal solution in terms of installation and operation costs. Also, it should be taken into consideration that summer overheating could be crucial in well insulated buildings. The climate projection data also affects overall heating and cooling balance in the building, as a monthly average temperature is expected to gradually rise. The prospective building energy consumption under historic, contemporary, and projected climate variability patterns is shown in Fig. 7.

Annual cooling demand, $\mathrm{kWh} / \mathrm{m}^{2}$

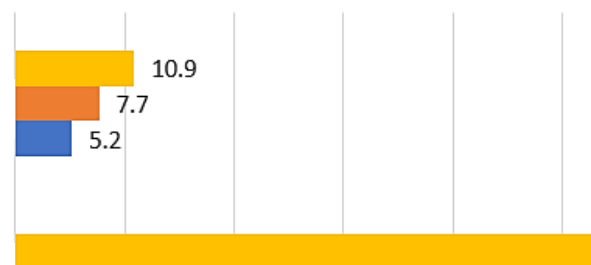

Annual heating demand, $\mathrm{kWh} / \mathrm{m}^{2}$

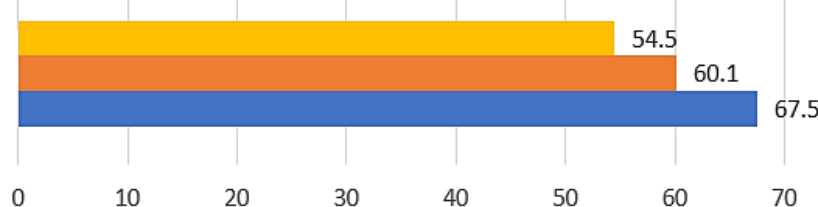

$\mathrm{kWh} / \mathrm{m}^{2}$

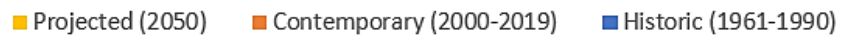

Fig. 7. Annual energy demand for space heating and cooling for the optimized model mapped out across varying climate pattern.

Table 4 summarizes space heating and cooling demand in reference to total thermal energy consumption of the building. As it is seen, over the coming decades the heating demand ratio 
is expected to be dropping by almost $10 \%$ (by 2050) at the expense of the increased cooling demand. The shift is driven by the changing weather pattern in favour of slightly warmer winter and summer seasons (Fig. 1).

Table 4. Annual Energy Demand for Space Heating and CoOling / Heat Recovery

\begin{tabular}{lllll}
\hline & $\begin{array}{l}\text { Annual heating demand, } \\
\mathbf{k W h} / \mathbf{m}^{2}\end{array}$ & $\begin{array}{l}\text { Annual cooling demand, } \\
\mathbf{k W h} / \mathbf{m}^{2}\end{array}$ & $\begin{array}{l}\text { Heating demand } \\
\text { ratio }\end{array}$ & $\begin{array}{l}\text { Cooling demand } \\
\text { ratio }\end{array}$ \\
\hline $\begin{array}{l}\text { Historic } \\
(1961-1990)\end{array}$ & 67.5 & 5.2 & $92.85 \%$ & $7.15 \%$ \\
$\begin{array}{l}\text { Contemporary } \\
(2000-2019)\end{array}$ & 60.1 & 7.7 & $88.64 \%$ & $11.36 \%$ \\
$\begin{array}{l}\text { Projected } \\
(2050)\end{array}$ & 54.5 & 10.9 & $83.33 \%$ & $16.67 \%$ \\
\hline
\end{tabular}

\section{Conclusion}

As of today, an average single-family house requires substantially more energy per floor area than a multi-apartment building to provide adequate indoor environment. This is attributed to the numerous factors, such as the thermal performance and quality of the building envelope, impact of linear thermal bridges, prevalence of natural ventilation as means to ensure air exchange, and other factors.

The present study examined simplified external window shading scenarios to avoid summer overheating without compromising the capture of solar heat gains in the winter. The results suggest that the building where no external shading elements were incorporated, would result in lower annual heating energy demand, while an integration of various external shading elements would compromise building's thermal performance in the winter by increasing the heating demand by up to $10 \%$, if referenced against the standard case. However, the climate projection analysis indicates that buildings that have been constructed in compliance with the regulatory codes that had been effective within the last decades (1990-2020) will be at higher risk of overheating in the summer. In line with the increasing winter temperatures, over the next decades a gradual shift is expected from focusing too extensively on the insulation thickness and airtightness of the building envelope to emphasizing the feasibility of the efficient mechanical ventilation system with heat recovery unit that offers great potential to optimize and balance heating and cooling loads in buildings.

At an optimized scenario that incorporates MVHR and enhanced thermal performance of the external building elements, the annual energy demand in the proposed single-family house would be reduced from $112 \mathrm{kWh} / \mathrm{m}^{2}$ to $67.5 \mathrm{kWh} / \mathrm{m}^{2}$, i.e., by $40 \%$, which is a significant step towards meeting nearly zero energy building criteria. Furthermore, in combination with external or insulated shading strategy that enables solar heat gain accumulation during the cold season, the annual energy savings are potentially higher.

\section{ACKNOWLEDGEMENT}

This work has been supported by the European Regional Development Fund project 'A new concept for low-energy ecofriendly house', Grant Agreement No 1.1.1.1/19/A/017.

This study has been carried out in collaboration with modular timber frame house manufacturer "WWL Houses" Ltd. 


\section{REFERENCES}

[1] Walsh A., Cóstola D., Labaki L. C. Review of methods for climatic zoning for building energy efficiency programs. Building and Environment 2017:112:337-350. https://doi.org/10.1016/j.buildenv.2016.11.046

[2] Directive 2012/27/EU of the European Parliament and of the Council of 25 October 2012 on energy efficiency, amending Directives 2009/125/EC and 2010/30/EU and repealing Directives 2004/8/EC and 2006/32/EC. Official Journal of the European Union 2012:L 315/1.

[3] Department for Environment Food \& Rural Affairs. Energy Use in Homes. 2005. [Online]. [Accessed: 14.03.2021]. Available: http://sciencesearch.defra.gov.uk/Default.aspx?Menu=Menu\&Module=More\&Location=None\&Complete $\mathrm{d}=0$ \&ProjectID $=15764$

[4] Ekström T., Bernardo R., Blomsterberg Å. Cost-effective passive house renovation packages for Swedish single-family houses from the 1960s and 1970s. Energy Buildings 2018:161:89-102. https://doi.org/10.1016/j.enbuild.2017.12.018

[5] Qiu Y., Kahn M. E. Impact of voluntary green certification on building energy performance. Energy Economics 2019:80:461-475. https://doi.org/10.1016/j.eneco.2019.01.035

[6] Güneralp B., et al. Global scenarios of urban density and its impacts on building energy use through 2050. Proceedings of the National Academy of Sciences of the Unated States of Amrecia 2017:114(34):8945-8950. https://doi.org/10.1073/pnas.1606035114

[7] Yang X., Zhang S., Xu W. Impact of zero energy buildings on medium-to-long term building energy consumption in China. Energy Policy 2019:129:574-586. https://doi.org/10.1016/j.enpol.2019.02.025

[8] Borodinecs A., Dzelzitis E., Kreslins A. General Requirements for the Energy Performance of Buildings in Latvia. Proceedings of Clima 2007 WellBeing Indoors 2007:321:1043

[9] Ozolinsh A., Jakovics A. Risks of condensate formation and mould growth in buildings under Latvian climate conditions. Latvian Journal of Physics and Technical Sciences 2013:44-53. https://doi.org/102478/lipts-2013-0032

[10] Xu C., Li S., Zou K. Study of heat and moisture transfer in internal and external wall insulation configurations. Journal of Building Engineering 2019:24:100724. https://doi.org/10.1016/j.jobe.2019.02.016

[11] Borodinecs, A., et al. Hydrothermal performance of the external wooded frame wall structure reinforced with ballistic panels. E3S Web of Conferences 2020:172:07005. https://doi.org/10.1051/e3sconf/202017207005

[12] Žogla G., et al. Energy Efficiency Improvement Potential in Historical Brick Building. Enviromental and Climate Technologies 2013 Conference proceedings 2013:3:60-65. https://doi.org/10.7250/iscect.2013.011

[13] Ozoliṇa L., Dobrāja K., Rošā M. The Design of Support Program for Energy Efficiency Improvement in Latvian Industry. Environmental and Climate Technologies 2013 Conference proceedings 2013:3:49-59. https://doi.org/10.7250/iscect.2013.010

[14] Borodinecs A., Geikins A., Smirnov S. Energy performance of temporary shelters. IOP Conference Series Materials Science and Engineering 2019:660(1):012017. https://doi.org/10.1088/1757-899X/660/1/012017

[15] Geikins A., et al. Typology of Unclassified Buildings and Specifics of Input Parameters for Energy Audits in Latvia. IOP Conference Series: Earth and Environmental Science 2019:290(1):012131. https://doi.org/10.1088/1755$1315 / 290 / 1 / 012131$

[16] Borodinecs A., et al. Retrofitting of fire stations in cold climate regions. Magazine of Civil Engineering 2019:90(6):8592. https://doi.org/10.18720/MCE.90.8

[17] Kumar D., et al. Comparative analysis of building insulation material properties and performance. Renewable and Sustainable Energy Reviews 2020:131:110038. https://doi.org/10.1016/j.rser.2020.110038

[18] Tettey U. Y. A., Dodoo A., Gustavsson L. Primary energy implications of different wall insulation materials for buildings in a cold climate. Energy Procedia 2014:61:1204-1207. https://doi.org/10.1016/j.egypro.2014.11.1056

[19] Petrovic B., et al. Life cycle assessment of a wooden single-family house in Sweden. Applied Energy 2019:251:113253. https://doi.org/10.1016/j.apenergy.2019.05.056

[20] Chen J., et al. Global socioeconomic exposure of heat extremes under climate change. Journal of Cleaner Production 2020:277:123275. https://doi.org/10.1016/j.jclepro.2020.123275

[21] Gorshkov A., Vatin N. I., Rymkevich P. P. Climate change and the thermal island effect in the millionplus city. Construction of Unique Buildings and Structures 2020:89:8902. https://doi.org/10.18720/CUBS.89.2

[22] Pathan A., et al. Monitoring summer indoor overheating in the London housing stock. Energy Buildings 2017:141:361378. https://doi.org/10.1016/j.enbuild.2017.02.049

[23] Laouadi A., Bartko M. Lacasse M. A. A new methodology of evaluation of overheating in buildings. Energy Buildings 2020:226:110360. https://doi.org/10.1016/j.enbuild.2020.110360

[24] Prozuments A., Borodinecs A., Zemitis J. Survey Based Evaluation of Indoor Environment in an Administrative Military Facility. Journal of Sustainable Architecture and Civil Engineering 2020:27(2):96-107. https://doi.org/10.5755/j01.sace.27.2.26079

[25] Baiburin A. K., et al. Heat loss through the window frames of buildings. Magazine of Civil Engineering 2019:85(1):314. https://doi.org/10.18720/MCE.85.1

[26] Tafakkori R., Fattahi A. Introducing novel configurations for double-glazed windows with lower energy loss. Sustainable Energy Technologies and Assessments 2021:43:100919. https://doi.org/10.1016/j.seta.2020.100919 
[27] Aburas M., et al. Thermochromic smart window technologies for building application: A review. Applied Energy 2019:255:113522. https://doi.org/10.1016/j.apenergy.2019.113522

[28] Huo H., et al. Analysis and optimization of external venetian blind shading for nearly zero-energy buildings in different climate regions of China. Solar Energy 2021:223:54-71. https://doi.org/10.1016/j.solener.2021.05.046

[29] Nikoofard S., Ugursal V. I., Beausoleil-Morrison I. Effect of external shading on household energy requirement for heating and cooling in Canada. Energy Buildings 2011:43(7):1627-1635. https://doi.org/10.1016/j.enbuild.2011.03.003

[30] Offiong A., Ukpoho A. U. External window shading treatment effects on internal environmental temperature of buildings. Renewable Energy 2004:29(14):2153-2165. https://doi.org/10.1016/j.renene.2003.11.015

[31] Santos-Herrero J. M., Lopez-Guede J. M., Flores-Abascal I. Modeling, simulation and control tools for nZEB: A state-of-the-art review. Renewable and Sustainable Energy Reviews 2021:142:110851. https://doi.org/10.1016/j.rser.2021.110851

[32] Godish T. Relationships between ventilation and indoor air quality: A review. Indoor Air 1996:6(2):135-145. https://doi.org/10.1111/j.1600-0668.1996.00010.x

[33] Seppänen O. A. Association of ventilation rates and $\mathrm{CO}_{2}$ concentrations with health and other responses in commercial and institutional buildings. Indoor Air 1999:9(4):226-252. https://doi.org/10.1111/j.1600-0668.1999.00003.x

[34] Engvall K., Wickman P., Norbäck D. Sick building syndrome and perceived indoor environment in relation to energy saving by reduced ventilation flow during heating season: A 1 year intervention study in dwellings. Indoor Air 2005:15(2):120-126. https://doi.org/10.1111/j.1600-0668.2004.00325.x

[35] Zhao L., Liu J. Operating behavior and corresponding performance of mechanical ventilation systems in Chinese residential buildings. Building Environment 2020:170:106600. https://doi.org/10.1016/j.buildenv.2019.106600

[36] Jiang Y., Chen Q. Study of natural ventilation in buildings by large eddy simulation. Journal of Wind Engineering and Industrial Aerodynamics 2001:89(13):1155-1178. https://doi.org/10.1016/S0167-6105(01)00106-4

[37] Cao X., Dai X., Liu J. Building energy-consumption status worldwide and the state-of-the-art technologies for zeroenergy buildings during the past decade. Energy and Buildings 2016:128:198-213. https://doi.org/10.1016/j.enbuild.2016.06.089

[38] USA DoE, et al. An Assessment of Energy Technologies and Research Opportunities. Quadrennial Technology Review. Washington: DoE, 2015:143-181.

[39] Rootzen J. Reducing Carbon Dioxide Emissions from the EU Power and Industry Sectors. Göteborg: Chalmers University of Technology, 2012.

[40] European Commission. Going climate-neutral by 2050: A strategic long-term vision for a prosperous, modern, competitive and climate-neutral EU economy. Luxembourg: Publications office of the European Union, 2019.

[41] Bardage S. L. Performance of buildings. Performance of Bio-based Building Materials 2017:335-383. https://doi.org/10.1016/B978-0-08-100982-6.00006-9

[42] Ji Y., et al. Air infiltration rate of typical zones of public buildings under natural conditions. Sustainable Cities and Society 2020:61(1):102290. https://doi.org/10.1016/j.scs.2020.102290

[43] Salehi A., Torres I., Ramos and A. Experimental analysis of building airtightness in traditional residential Portuguese buildings. Energy and Buildings 2017:151:198-205. https://doi.org/10.1016/j.enbuild.2017.06.037

[44] Chartered Institution of Building Services Engineers. TM59: Design methodology for the assessment of overheating risk in homes. London: CIBSE, 2017.

[45] Alev Ü., et al. Renovation alternatives to improve energy performance of historic rural houses in the Baltic Sea region. Energy and Buildings 2014:77:58-66. https://doi.org/10.1016/j.enbuild.2014.03.049

[46] Jokisalo J., et al. Building leakage, infiltration, and energy performance analyses for Finnish detached houses. Building and Environment 2009:44(2):377-387. https://doi.org/10.1016/j.buildenv.2008.03.014

[47] Brinks P., Kornadt O., Oly R. Air infiltration assessment for industrial buildings. Energy and Buildings 2015:86:663676. https://doi.org/10.1016/j.enbuild.2014.10.040

[48] Bjørneboe M. G., Svendsen S.,. Heller A. Evaluation of the renovation of a Danish single-family house based on measurements. Energy and Buildings 2017:150:189-199. https://doi.org/10.1016/j.enbuild.2017.04.050

[49] Sakulpipatsin P., Boelman E. C., Cauberg H. Heat recovery in residential ventilation systems from an exergy perspective. Healthy Buildings: Creating a Healthy Indoor Environment for People, Proceedings 2006.

[50] Ana Picallo-Perez I. G.-A., et al. Ventilation of buildings with heat recovery systems: Thorough energy and exergy analysis for indoor thermal wellness. Journal of Building Engineering 2021:39:102255. https://doi.org/10.1016/j.jobe.2021.102255

[51] Tommerup H., Svendsen S. Energy savings in Danish residential building stock. Energy and Buildings 2006:38(6):618-626. https://doi.org/10.1016/j.enbuild.2005.08.017

[52] D'Agostino D., et al. Assessing Nearly Zero Energy Buildings (NZEBs) development in Europe. Energy Strategy Reviews 2021:36:100680. https://doi.org/10.1016/j.esr.2021.100680 